\title{
Patient with neuroblastoma complicated by giantthrombus of an inferior vena cava with intracardiac extension
}

Bakhram Zhumadullayev $^{1}$, Ainur Akhmetkaliyeva ${ }^{2}$, Anzhelika Meiramova $^{2}$, Saniya Baiturova ${ }^{2}$ ${ }^{I}$ Researchcenterfor pediatrician and children
surgery,Almaty, Kazakhstan
${ }^{2}$ National research center for maternal and child health
of the corporate fund "UMC», Astana, Kazakhstan

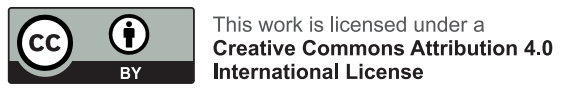

J CLIN MED KAZ 2017; 3(45 SUPPL 3):70-72

Автор для корреспонденции: Ахметкалиева А.С., Национальный научный центр материнства и детства корпоративного фонда «University Medical Center», отделениедетскойонкологии-4. Адрес: улицаТуран 32, Астана, Казахстан. Телефон: +77018475840. E-mail: ainur_sagatovna@mail.ru.

\author{
ТӨМЕНГІ КАҚПА ВЕНАСЫНАН ОН ЖАҚ ЖУРЕКШЕГЕ ДЕЙІН \\ СОЗЫЛҒАН ГИГАНТТЫ ТРОМБПЕН АСКЫНҒАН НЕЙРОБЛАСТО- \\ МАСЫ БАР НАУКАС \\ Жумадуллаев Б.М. ${ }^{1}$, Ахметкалиева А.С. ${ }^{2}$, Мейрамова А.К. ${ }^{2}$, \\ Байтурова С.М. ${ }^{2}$ \\ ${ }^{1}$ Педиатрия және балалар хирургиясы ғылыми орталығы, Алматы, Қазахстан \\ ${ }^{2}$ «UMC» корпоративтік қорының Ана мен бала ұлттық ғылыми орталығы, Астана, Қазақстан
}

ПАЦИЕНТ С НЕЙРОБЛАСТОМОЙ ОСЛОЖНЕННОЙ ГИГАНТСКИМ ТРОМБОМПРОТЯЖЕННОСТЬЮ ОТ НИЖНЕЙ ПОЛОЙ ВЕНЫ ДО ПРАВОГО ПРЕДСЕРДИЯ

Жумадуллаев Б.М.', Ахметкалиева А.С. ${ }^{2}$, Мейрамова А.К. ${ }^{2}$, Байтурова С.M. ${ }^{2}$

'Научныйцентрпедиатрииидетскойхирургии, Алматы, Казахстан

${ }^{2}$ Национальныйнаучныйцентрматеринстваидетствакорпоративногофонда«UMC», г. Астана, Казахстан

\section{Introduction}

Neuroblastoma is the most common extracranial solid tumor in childhood. Before the age of one year neuroblastoma occurs in $50 \%$ of diagnosed neoplasms, moreover by age 5 it occurs in $90 \%$. This malignancy was described by James Wright in 1910, and was named because cells were associated with fibrils in arrangements similar to neuroblasts.Neuroblastoma arise in tissues of the sympathetic nervous system and can be in different part of body. In all cases neuroblastoma is diagnosed by imaging (MRI), also in $90 \%$ patients have catecholamine acids in urine and high level of Neuron-specific enolase. Case witch we had been presented is a tremendous clinical challenge.

\section{Description of clinical case}

3 years old girl had admitted to National research center of mother and child health

Astana, Kazakhstan in September 2016 with fever, weight loss, diffuse abdominal pain, loss of appetite. During physical examination revealed palpable and motionless mass in the upper left side of abdomen. On ultrasonography investigation solid tumor of left retroperitoneal space had beendetected, sizeswas119x95x112mm.An abdominal MRI had shownthe formation an irregularly-oval shaped solid structure with precise uneven contours about 109x86x93 mm, in the projection of the left adrenal gland, compressing left kidney but without invasion on it. Alsothere was revealed thrombus growing from inferior vena cava and filling the cavity of right atrium, with sizes $5 \mathrm{~cm}$ in width and $13 \mathrm{~cm}$ in length, prolap. Laboratory findings:NSE $-139.40 \mathrm{ng} / \mathrm{ml}$ (normal value: 1-15 ng/ml), AFP 3,12 MU/ml (normal value: $1-5 \mathrm{MU} / \mathrm{ml}$ ), BMA $29,13 \mathrm{mg}$ (normal value: 1-5 $\mathrm{mg}$ ). Myelogram:accumulations of small blue round tumor cells, typical for neuroblastoma. With the aim of decreasing of sizes of tumor 3 cycles non-adjuvant chemotherapy N5/N6 according to NB2004 was provided. After these courses of chemotherapy tumor significantly decreased in sizes, it becomes $46 \times 37 \mathrm{~mm}$ in diameter. Giant trombus of IVC and RA was also decreased in sizes 10x11 mm (previous sizes 3,35x5,07x3,67). IVC is dilated till 5,5 x 5,9 мм(previous sizes 1,6 cm). In January 2017radical operation of tumor resection was made. Resection margins were clear. Histology: Morphological picture correspondsto a poorly differentiated neuroblastoma with pathomorphosis 3rd degree. Child was carried out more 3 cycles of adjuvant chemotherapy. During all period of treatment patient took additional anticoagulant therapy by low doses of Heparin and Warfarin. The EchoCG after 6 courses of chemotherapy (N5/ N6) had shown absence ofIVC thrombosis, and thrombus in the cavity of RA significantly decreased in sizes $8,0 \times 6,3 \mathrm{~mm}$. Further treatment of this child contained high dose chemotherapy with autologous stem cell transplantation according to NB 2004 protocol and external beam radiotherapy on the tumor bed (30Gy). Now patient is in clinical and radiological remission.

- Histology findings:Homer Wright rosettes are a type of rosette in which differentiated tumor cells surround the neuropil 


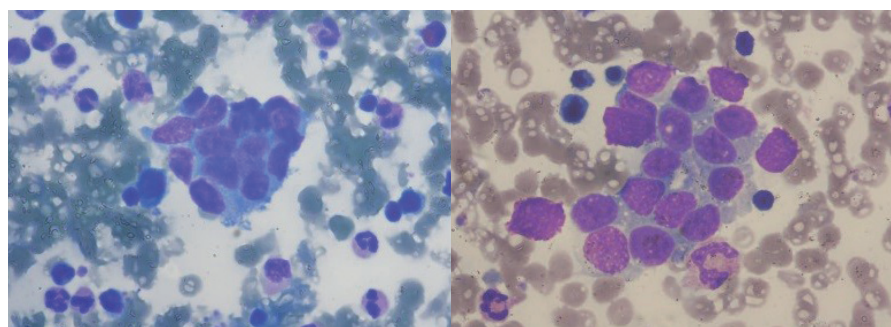

- MRI at the moment of diagnosis

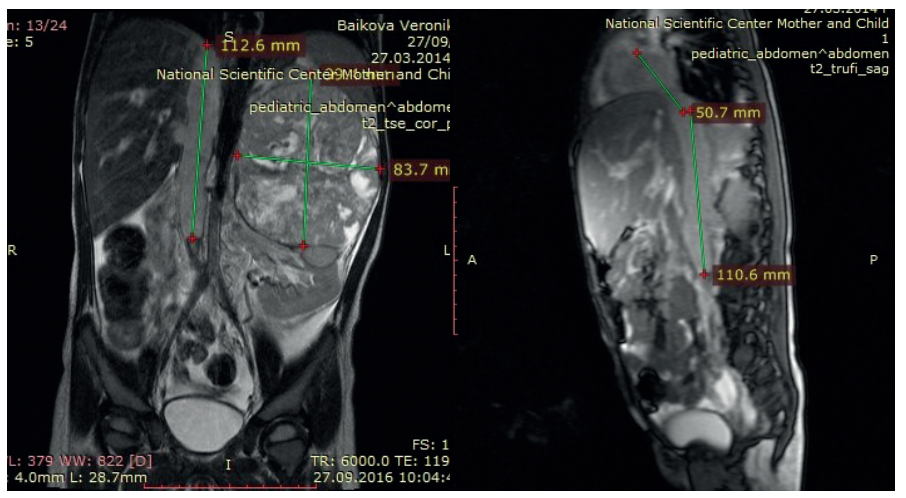

- MRI after neo-adjuvant chemotherapy, before operation

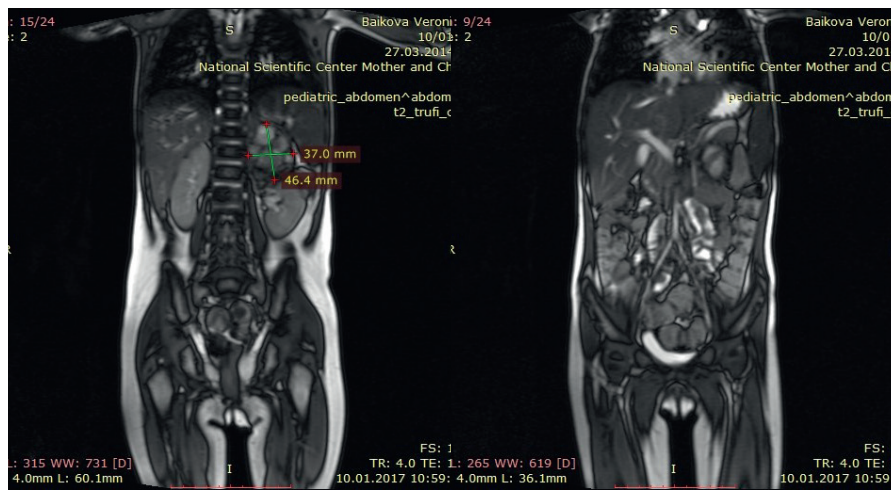

- EchoCG at the moment of diagnosis

In the region of right athrium there is tissue mass (thrombus), sizes $3,35 \times 5,07 \times 3,67$, arising from IVC, have prolapse in the cavity of left athrium. IVC is dilated till $1,6 \mathrm{~cm}$, filled by thrombus.

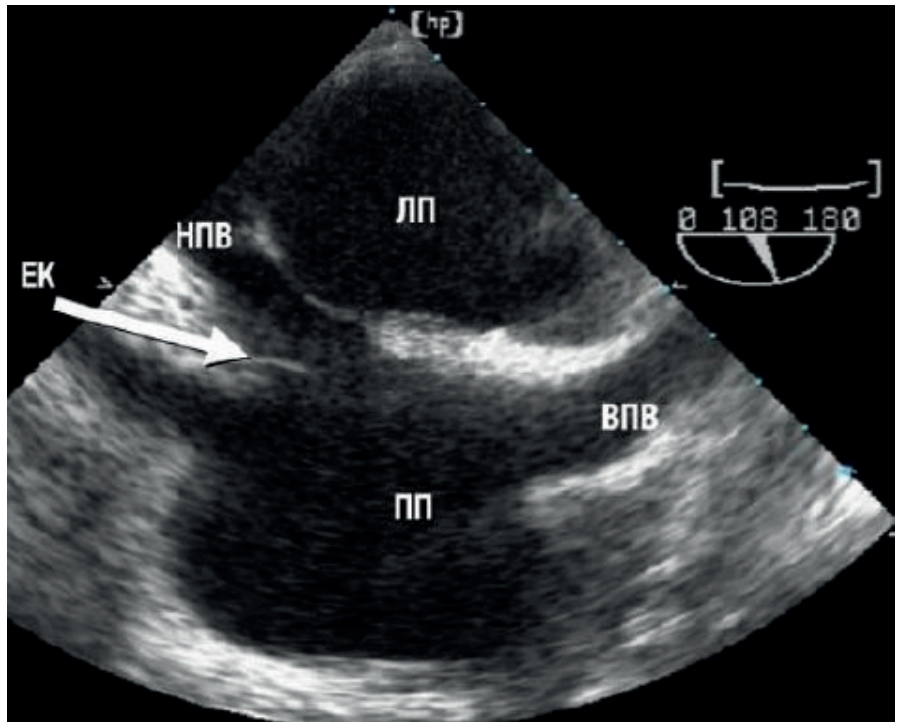

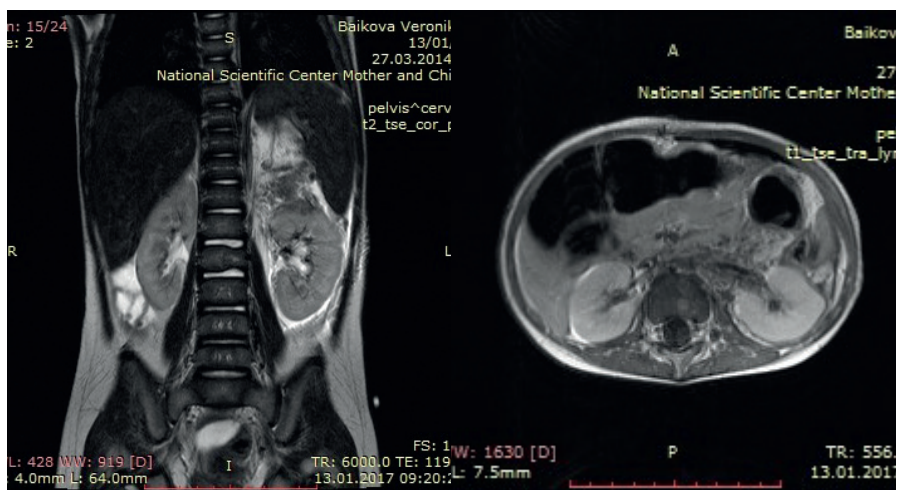

- MRI after operation(condition after total operation)

EchoCGafter 6 courses of N5/N6

- IVC is normal, thrombus is absent

- In the cavity of right athrium there is tissue mass (thrombus), sizes $8,0 \times 6,3 \mathrm{~mm}$ (previous sizes $3,35 \times 5,07 \times 3,67$ ). IVC is normal, thrombus is absent (previous sizes $1,6 \mathrm{~cm}$ ).

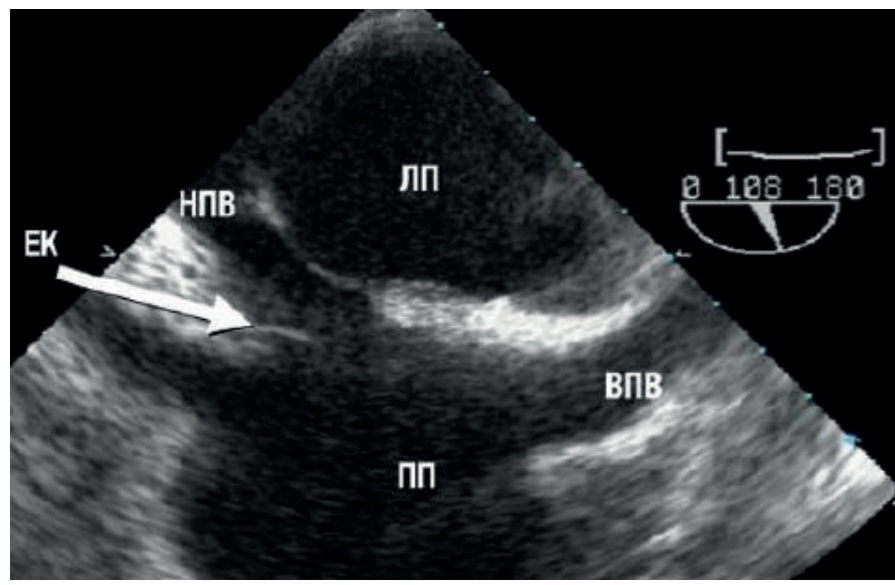

\section{Discussion}

Wilms' tumor presenting with extension into the inferior vena cava and right atrium is thus rare and renders the affected child with additional cardiovascular complications and operative risks. As a result of the uncommon occurrence, a consensus on management based on prospective study would be difficult. The present report is supportive of the use of preoperative chemotherapy in the initial management of advanced Wilms' tumor extending into the right atrium[2]. In literature survey there was found the review of the charts of 155 children with WT treated between 1983 and 2005, and analysis of 16/155 $(10.3 \%)$ children with WT who presented cavoatrial tumor extension, being 8/16 IVC and 8/16 atrial thrombus. Preoperative chemotherapy was able to reduce thrombus extension in $8 / 11$ $(73 \%)$ treated patients and cardiopulmonary bypass (CBP) was avoided in 2 patients with atrial thrombus. Surgical resection of tumor and thrombus was successful in all cases, receiving or not preoperative chemotherapy and overall survival was similar in both groups[3]. Therefore two main strategies of treatment of these nephroblastoma patients present nowadays: active surgical resection with $\mathrm{CBP}$ or preoperative chemotherapy, which reduce sizes of thrombus significantly, and it gives opportunity to cure patients without aggressive surgery. 


\section{Conclusion}

1. Neuroblastoma is one of the frequent solid tumors in pediatric oncology, but extremely rare it can be complicated by thrombosis of inferior vena cava with intracardiac extension. This process probably isdue to the disorders in rheologic properties of bloodbecause of huge number of tumor cellscirculating in the bloodstream, and we regarded it asproto-oncogenic thrombus.

2. Differential diagnosis between nephroblastoma and neuroblastoma in preoperative period should be based not only on the radiology findings, but also on the results of specific neuroblastoma markers.

3. Neuroblastoma in high risk group patients is very sensitive to chemotherapy, therefore the proto-oncogenic thrombus after treatment by intensive neo-adjuvant chemotherapy in combination with anticoagulant therapy can dissolve thrombosis without aggressive surgical intervention.

\section{References:}

1. Pannek J1, Goepel M, Kremens B, Otto T, Sadony V. Surgical management of Wilms tumor with intracardiac neoplastic extension. Thorac Cardiovasc Surg. 1994;42(2):108-11.

2. Lee AC1, Saing H, Leung MP, Mok CK, Cheng MY. Wilms' tumor with intracardiac extension: chemotherapy before surgery. Pediatr Hematol Oncol. 1994; 11(5):535-40.

3. Cristofani LM1, Duarte RJ, Almeida MT, Odone Filho V, Maksoud JG, Srougi M. Intracaval and intracardiac extension of Wilms' tumor. The influence of preoperative chemotherapy on surgical morbidity. IntBraz J Urol. 2007;33(5):683-9;

4. Genevieve Gaetan, Alain Ouimet, Chantale Lapierre, Pierre Teira, and HerveSartelet. Neuroblastoma presenting like a Wilms' tumor with thrombus in inferior vena cava and pulmonary metastases: a case series Springerplus. 2014; 3: 351.

5. Maureen Dumba, Noorulhuda Jawad, Kieran McHugh. Neuroblastoma and nephroblastoma: a radiological reviewCancer Imaging. 2015; 15(1): 5 .

6. Garrett M. Brodeur, Rochelle Bagatell. Mechanisms of neuroblastoma regression.Nat Rev ClinOncol. 2014; 11(12): 704-713. 